\title{
THE RELATIONSHIPS BETWEEN SECTOR WHERE SMES OPERATING, AND THEIR STRATEGIES, INNOVATION TYPES \& INNOVATION BARRIERS
}

\begin{abstract}
Adnan KALKAN
Özlem Çetinkaya BOZKURT

Olcay KILINÇ

Mehmet Akif Ersoy University, Turkey

\section{ABSTRACT}

Innovation is what we may call the most significant means of changing and rearranging life though research-and-development and production of technology, and including the outcomes in economy. Improvements to innovation support rapid change in information production. Therefore it is crucial for businesses to apply innovation management to survive and prosper in this age of information. From this point of view, the research aims to investigate the characteristics of SMEs concerning their innovation and whether they have developed effective strategies. Moreover, it aims to ascertain which strategies, innovation barriers and types they employ. We retrieved the data used in this study from The Burdur Chamber of Commerce and Industry (BUTSO). We collected data through a survey and tested the hypotheses using some analyses. The results of the study showed that there are some relations between some characteristics of SMEs and strategies, innovation types and barriers.
\end{abstract}

Keywords: SMEs, Sector, Strategies, Barriers to Innovation, Innovation Types

\section{INTRODUCTION}

In recent years, especially for the industrial sector, innovation has become an important issue. Businesses consider innovation as an important element to increase their profits and market shares. Today's economy is based on information which is a product resulting from the combination of R\&D and innovation. In the information age where it is necessary to adapt rapid change and innovation, SMEs should give greater consideration to $R \& D$ and innovation issues to remain competitive. The main factor that determines the strength of competition is R\&D and, high and sustainable productivity growth source of innovation.

During a country or sector-wide review, emerging developments and rapidly evolving fields of advanced technology depend significantly on the capability of SMEs, i.e. if they are capable of transforming new ideas into marketable products. The flexible structures of SMEs provide more advantages than that of large enterprises for innovation activities. SMEs which adapt easily to all innovations concerning technology, production methods and marketing can be easily constructed for the commercialization of the product resulting from $R \& D$. Innovation-oriented strategies make important contributions, ensuring the protection and sustainability of presence and increasing competitiveness for SMEs.

In this survey we aim to identify the relationships between characteristics of SMEs and strategies, innovation types and barriers to innovation. In this study, SMEs operating in various sectors in Burdur were chosen as the research population. Data obtained from those 110 questionnaires were analyzed through the SPSS statistical packet program and the proposed relations were tested through Kruskal Wallis and K-Means Cluster analyses.

\section{Theoretical Framework and Hypotheses}

The transformation of a new product into commercial product which meets the needs of customers constitutes innovation value (Carlson and Wilmot, 2006: 56). Innovation, as a concept, describes a process (refresh/renewal) and a result (innovation). Businesses, depending on the innovation-related 
expectations determine an innovation strategy. The process of determination of innovation strategy is similar to process of determination of business management strategy. Because business basic strategies and innovation strategies is highly depend on each other (Ecevit and Isı, 2011: 540). It is not possible to perform the necessary steps of innovation management for business without effective strategy (Cormican and O'sullgvan, 2004: 819). Actuation continuous innovation in business is related to strategy development and, if appropriate strategies are not developed innovation will affected adversely (Mone et al., 1998: 115). To become innovative, businesses should be open to change, follow up innovations in their fields and have a flexible organizational structure (Dengiz ve Belgin, 2007: 267).

\section{SMEs}

The SMEs plays an important role in creating jobs and wealth in the Turkish economy. SMEs are an essential source of jobs, entrepreneurial spirit and innovation and are thus very important for fostering competitiveness (Fatoki, 2011: 193). The Turkish economy is characterized by a high growth rate (8.9\% for Turkey and $1.8 \%$ for EU in 2010), relatively high inflation (Consumer Price Index) rate (6.4\% for Turkey and $2.6 \%$ for EU in 2010) and a relatively high rate of unemployment (10.7\% for Turkey and 9.7\% for EU in 2010) compared to EU-27 (TUIK and Eurostat). SMEs employ 76.7\% of the working population and the share of the SMEs in production is 38\% in Turkey (Cansiz, 2008: 5).

\section{Innovation and Innovation Types}

Due to fierce competition in the marketplace, globalization and an explosion of technology in recent years, innovation and differentiation are considered as a necessity for every company. At the same time, to achieve market success and sustain a competitive advantage, businesses need to exploit new opportunities, develop new products and/or services and markets (Tajeddini, 2010: 221).

Innovation is defined as "implementing new ideas that create value". This generic description refers to the various types of innovation such as product development, the deployment of new process technologies, and also management practices. This means the adoption of new products and/or processes to increase competitiveness and overall profitability, based on customer needs and requirements (Leskovar, 2007: 535).

The Oslo guide (2005: 51) has given a large extent place to the definitions about innovation and the types of innovation. In these definitions, four types of innovation are discussed. These are product innovation, process innovation, marketing innovation and organizational innovation.

Product innovations include both presentation of new products and services to market, and major improvements in the functional or user characteristics of existing goods and services (Oslo guide, 2005: 52). Process innovation includes major changes in methods, equipments and/or software. A new type of production method can be an example for process innovation. Marketing innovations, to increase the company's sales, aim to respond the customers' needs more successful way, open new markets or locate a company's product in market in a new way. The new sales techniques, new financial methods (venture capital) can be seen as marketing innovations. Organizational innovation can be defined as implementing a new organizational method in commercial practices, workplace organization or external relations for a company (Antonioli, et al., 2004: 19). Organizational innovations in commercial practices, involve the realization of new methods of organizing routines and procedures for conducting the work.

\section{Strategies}

Strategy is the outcome of decisions made to guide an organization with respect to environment, structure and processes that influence its organizational performance. There are several typologies. According to Zahra and Pearce (1990) and Smith et al. (1989), the most popular typology is Miles and Snow's. Miles and Snow's typology consists of four types of business strategy defined as prospector, defender, analyzer and reactor (Croteau and Bergeron, 2001: 78-79). If management does not select 
one of these strategies, then the organization will be slow to respond to opportunities and probably show an ineffective performance in its sector (Hambrick, 1983: 8).

Organizations supporting the prospector strategy wish to have access to the largest possible market. They are characterized by their repeated efforts to innovate and bring changes in their industry. Organizations favoring the defender strategy have a restricted market and stress production efficiency. They emphasize the excellence of their products, the quality of their services and their lower prices. Organizations implementing the analyzer strategy share both prospector and defender characteristics, but in moderation. They seek to be first to introduce some new products, but are satisfied to remain in second place with certain products that offer a good quality/price ratio. Finally, organizations supporting the reactor strategy ignore new opportunities, and cannot maintain markets already acquired or take true risks (Croteau and Bergeron, 2001: 78-79).

\section{Barriers to Innovation}

Even in industrialized countries, SMEs are expected to face relatively more barriers to innovation than large firms. As SMEs have comparatively more inadequate internal resources and lack of expertise, the interactive character of innovation in their case becomes even more intense than in large firms. This is one of the reasons that higher importance is attached to barriers. It is generally believed that once SME entrepreneurs identify their innovation barriers, study their impacts and take actions to eliminate them, then the natural flow of innovation will be re-established and maintained. Because innovation is not an automatic or spontaneous process it requires entrepreneurs to provide motivation, effort and risk acceptance to proceed (Demirbaş, 2005: 6).

Hadjimanolis grouped the barriers to innovation in two different ways: Internal barriers and external barriers. External barrier was grouped as supply, demand and environmental. Supply barrier was diversified as technological knowledge, financial and missing material. Demand barriers consist of customer needs, innovation seen as a risk, internal and international market limits. It can be said that environmental barriers consist of the various government regulations, competition measures and laws. A part of the internal barriers is due to the insufficient resources of business. The lack of financial power, the lack of technical expertise, management, culture, etc. were given as an example for internal barriers. According to the research, the other part of internal barriers is due to the lack of system. The old type of accounting systems can be given as an example. The other part of internal barriers is due to the lack in human resources. The management attitude to risk or the resistance of employees to innovation can be given as an example (Günay, 2007: 32-33).

Piatier (1984) differentiated barriers as external to the firm (supply, demand and environmental barriers) and internal to the firm (resource related, culture and systems related and human nature related). Supply barriers include difficulties in obtaining technological information, raw materials, and finance. Demand barriers have to do with customer needs, their perception of the risk of innovation, and domestic or foreign market limitations. Environmental ones include various government regulations, antitrust measures, and policy actions. Resource related, e.g. lack of internal funds, technical expertise or management time; culture and systems related e.g. out-of date accountancy systems; and human nature related, e.g. attitude of top manager to risk or employee resistance to innovation (Demirbaş. 2005: 6).

\section{Development of Hypotheses}

In the light of the literature, we argued that there were some relations between the characteristics of SMEs and their innovation types, strategies, internal and external innovation barriers, and proposed some hypotheses following:

$H_{1}$ : There is a relationship between sector where SMEs operate and external innovation barriers.

$\mathrm{H}_{2}$ : There is a relationship between sector where SMEs operate and internal innovation barriers.

$H_{3}$ : There is a relationship between sector where SMEs operate and innovation types.

$H_{4}$ : There is a relationship between sector where SMEs operate and strategies. 


\section{Research Method}

\section{Research Goal}

In this survey we aim to identify the relationships between characteristics of SMEs and strategies, innovation types and barriers to innovation. To test the propositions, a field survey using questionnaires was conducted. The contribution of this research should be discussed with respect to the progress made in methodological and empirical knowledge about innovation, strategies and innovation barriers. This paper aims to present barriers to innovation and strategies in SMEs. The data is analyzed empirically. In this study, strategies, innovation types and barriers to innovation in SMEs have been investigated and tested.

\section{Sample and Data Collection}

In this study, SMEs operating in various sectors in Burdur were chosen as the research population. Randomly selected 110 SMEs were taken as the sample of the research. The number of SMEs registered to Burdur Commerce and Industry Chamber (BUTSO) is 460 (population) in Burdur in 2012. The rate of randomly selected sampling is $24 \%$. Analysis has been carried out using data which were obtained from the SMEs in Burdur by using a questionnaire form. In this study, respondents were asked to rate on five-point Likert scales (1: certainly disagree, ...., 5: certainly agree). The respondents were chosen from the top and mid-level managers in SMEs. Questionnaires were subjected to respondents by interviewing face to face. Data obtained from those 110 questionnaires were analyzed through the SPSS statistical packet program and the proposed relations were tested through Kruskal Wallis and K-Means Cluster analyses.

\section{Analyses and Results}

First the Descriptive Statistics test was applied to data in order to obtain descriptive information about SMEs. The values obtained from the test are given in Table 1.

Table 1. Descriptive Statistics for SMEs.

\begin{tabular}{|c|c|c|c|c|c|c|}
\hline \multirow{2}{*}{$\begin{array}{ll} & \text { Subjects } \\
\text { Sectors } & \end{array}$} & \multirow[t]{2}{*}{$\%$} & \multicolumn{5}{|c|}{ Descriptions } \\
\hline & & Production & Service & Trade & & \\
\hline & $\%$ & 46.4 & 35.5 & 18.1 & & \\
\hline \multirow[t]{2}{*}{ \# of Employees } & & $1-10$ & $11-50$ & Others & & \\
\hline & $\%$ & 47.3 & 41.8 & 10.9 & & \\
\hline \multirow[t]{2}{*}{ \# of University Graduates } & & $1-10$ & $11-50$ & Others & & \\
\hline & $\%$ & 86.4 & 10.9 & 2.7 & & \\
\hline \multirow[t]{2}{*}{ Duration of Activity (years) } & & $1-5$ & $6-10$ & $11-15$ & $16-20$ & $>20$ \\
\hline & $\%$ & 25.5 & 27.3 & 16.4 & 8.2 & 22.7 \\
\hline \multirow[t]{2}{*}{$\begin{array}{l}\text { R\&D Expenditures/Total } \\
\text { Capital }\end{array}$} & & $0 \%$ & $<1 \%$ & $1-5 \%$ & $6-10 \%$ & $>11 \%$ \\
\hline & $\%$ & 41.8 & 18.2 & 20 & 12.7 & 7.3 \\
\hline
\end{tabular}

The number of SMEs which has the number of university graduates among the 1-10 is higher in production (47 enterprises) than that of in service (29 enterprises). This number is the least in trade (19 enterprises).

Table 2. The Number of University Graduates in SMEs According to Sectors (A2* A4 Crosstabulation)

\begin{tabular}{|cccccccc|}
\hline & \multicolumn{9}{c}{$A 4$} & \multicolumn{1}{c|}{ Total } \\
& Variables & $1-10$ & $11-50$ & $51-100$ & $>250$ & $1-10$ \\
\hline \multirow{2}{*}{ A2 } & Production & 47 & 4 & 0 & 0 & 51 \\
& Service & 29 & 1 & 0 & 0 & 20 \\
& Trade & 19 & 7 & 2 & 1 & 39 \\
\hline \multicolumn{2}{r}{ Total } & 95 & 12 & 2 & 1 & 110 \\
\hline
\end{tabular}


In this study, sector as independent variables, innovation types with twenty dimensions, internal innovation barriers with nineteen dimensions, external innovation barriers with twenty three dimensions and strategies with seventeen dimensions as dependent variables have been chosen. Here, the relationships between dependent and independent variables have been investigated and measured. With regard to this issue various hypotheses have been developed and the accuracy of these hypotheses was investigated. According to Kolmogorov-Smirnov $(\mathrm{n}=110>29)$ normality test, it was determined that none of the distributions (Asyp. Sig. < .05) did not conform to normal distribution (Table 3).

Table 3. One-Sample Kolmogorov-Smirnov Test Values

\begin{tabular}{|lccc|}
\hline \multicolumn{1}{|c}{ Variables } & $\begin{array}{c}\text { Kolmogorov- } \\
\text { Smirnov Z }\end{array}$ & $\begin{array}{c}\text { Tot. Var. } \\
\text { Explained }\end{array}$ & $\begin{array}{c}\text { Asymp. } \\
\text { Sig. (2-tailed) }\end{array}$ \\
\hline Strategies & .850 & 59.58 & .000 \\
Innovation Types & .833 & 65.27 & .000 \\
Barriers to Innovation & .710 & 69.29 & .000 \\
\hline
\end{tabular}

The reliability coefficients for variables are given in Table 4.

Table 4. Cronbach Alpha Values

\begin{tabular}{|lccc|}
\hline \multicolumn{1}{c}{ Variables } & $\alpha$ & $F$ & Sig. \\
\hline Innovation Types & .906 & 19.506 & .000 \\
Barriers to Innovation & .915 & 14.861 & .000 \\
Strategies & .889 & 13.115 & .000 \\
Totally & .919 & 24.161 & .000 \\
\hline
\end{tabular}

Alpha coefficients obtained were accepted because they were higher than 0.50, as defined by Bagozzi and Yi (1988), and 0.70 as defined by Nunnally (1978), respectively. Hypotheses were tested by applying the Kruskal-Wallis statistical method because the distribution of the data did not conform to normal distribution.

According to hypothesis test results, it was seen that the sector affected the idea of taking the support from institutions and organizations was difficult due to the bureaucratic practices dimension which was one of the external innovation barriers (Sig. .038<.05).

$H_{1}$ : There is a relationship between sector where SMEs operate and external innovation barriers.

As a result of non-hierarchical cluster analysis (K-Means Cluster Analyses), sectors were clustered under three groups. Cluster members are service, production and trade.

According to final cluster centers table, the idea of taking the support is difficult due to the bureaucratic practices in trade enterprises is more dominated than the others (Table 5).

Table 5. Mean Values of Sectors for External Innovation Barriers

\begin{tabular}{|lcccc|}
\hline \multicolumn{1}{|c}{ Variables } & $\begin{array}{c}\text { Service } \\
(\mu)\end{array}$ & $\begin{array}{c}\text { Production } \\
(\mu)\end{array}$ & $\begin{array}{c}\text { Trade } \\
(\mu)\end{array}$ & Sig. \\
\hline $\begin{array}{l}\text { The idea of taking the support from institutions and } \\
\text { organizations is difficult due to the bureaucratic practices }\end{array}$ & 2.76 & 3.42 & 4.09 & .038 \\
\hline
\end{tabular}


According to hypothesis test results, it was seen that the sector affected the resistance of employees to innovation dimension which was one of the internal innovation barriers (Sig. .003 < .05).

$\mathrm{H}_{2}$ : There is a relationship between sector where SMEs operate and internal innovation barriers.

According to final cluster centers table, the resistance of employees to innovation is higher in trade enterprises than the others (Table 6); that is, employees in trade business are more anti-innovation than the others.

Table 6. Mean Values of Sectors for Internal Innovation Barriers

\begin{tabular}{|ccccc|}
\hline Variables & $\begin{array}{c}\text { Service } \\
(\mu)\end{array}$ & $\begin{array}{c}\text { Production } \\
(\mu)\end{array}$ & $\begin{array}{c}\text { Trade } \\
(\mu)\end{array}$ & Sig. \\
\hline The resistance of employees to innovation & 1.82 & 2.63 & 3.45 & .003 \\
\hline
\end{tabular}

According to hypothesis test results, it was seen that the sector affected at least one product patent belonging to SMEs (Sig. .033 < .05) and to keep the records of the process time (Sig. .005 $<.05$ ) dimensions which were innovation types (product and process innovation). Therefore;

$H_{3}$ : There is a relationship between sector where SMEs operate and innovation types.

In final cluster centers table, it was seen that having at least one product patent and keeping the records of the process time is higher in SMEs operating in production than that of others (Table 7).

Table 7. Mean Values of Sectors for Innovation Types

\begin{tabular}{|lcccc|}
\hline \multicolumn{1}{|c}{ Variables } & $\begin{array}{c}\text { Service } \\
(\mu)\end{array}$ & $\begin{array}{c}\text { Production } \\
(\mu)\end{array}$ & $\begin{array}{c}\text { Trade } \\
(\mu)\end{array}$ & Sig. \\
\hline $\begin{array}{l}\text { At least one product patent belonging to SMEs } \\
\text { (product innovation) }\end{array}$ & 1.81 & 3.32 & 2.22 & .033 \\
$\begin{array}{l}\text { To keep the records of the process time (process } \\
\text { innovation) }\end{array}$ & 2.23 & 4.32 & 3.51 & .005 \\
\hline
\end{tabular}

According to hypothesis test results, it was seen that the sector affected becoming an innovation leader in sector $($ Sig. .032 $<.05)$ and showing the best performance in a narrow market $($ Sig. .006 $<.05)$ dimensions which were strategies. Therefore;

$H_{4}$ : There is a relationship between sector where SMEs operate and strategies.

In final cluster centers table, it was seen that becoming an innovation leader and showing the best performance in a narrow market are less popular in trade business than the other sectors. Secondly, becoming an innovation leader in sector is higher in SMEs operating in production than that of others. In addition to these, showing the best performance in a narrow market is higher in SMEs operating in service than that of others (Table 8).

Table 8. Mean Values of Sectors for Strategies

\begin{tabular}{|lcccc|}
\hline \multicolumn{1}{|c}{ Variables } & $\begin{array}{c}\text { Service } \\
(\mu)\end{array}$ & $\begin{array}{c}\text { Production } \\
(\mu)\end{array}$ & $\begin{array}{c}\text { Trade } \\
(\mu)\end{array}$ & Sig. \\
\hline $\begin{array}{l}\text { To become an innovation leader in sector (prospector } \\
\text { strategy) }\end{array}$ & 2.76 & 4.20 & 1.56 & .032 \\
$\begin{array}{l}\text { To show the best performance in a narrow market } \\
\text { (defender strategy) }\end{array}$ & 3.93 & 3.36 & 1.89 & .006 \\
\hline
\end{tabular}


This survey, which is conducted on SMEs in Burdur, Turkey survived relations among the characteristics of SMEs and strategies, innovation types and innovation barriers. The most striking result to emerge from data is that there are some relations among sector in which SMEs operate and external and internal innovation barriers, innovation types and strategies which is followed by SMEs. Therefore, $\mathrm{H}_{1}$ (there is a relationship between sector and external innovation barriers), $\mathrm{H}_{2}$ (there is a relationship between sector and internal innovation barriers), $\mathrm{H}_{3}$ (there is a relationship between sector and innovation types) and $\mathrm{H}_{4}$ (there is a relationship between sector and strategies) are supported. According to Demirbaş (2005) lack of government's R\&D and technology policy from formal barriers; "Informal economy's negative impact on investment" from informal barriers; "high cost of innovation" and "lack of appropriate source of finance" from environmental barriers and "lack of qualified personnel" from skill barriers, are the most important variables, and they have a significant effect on the entrepreneurs' innovation decisions in Turkey.

According to Örücü at all (2011), as the number of employees increases, the success of making innovation for businesses also increases, making innovation does not show differences according to the formal structure of SMEs and the share of expenditure devoted to R\&D plays an important role in determining innovation strategies.

Çalıpınar and Baç (2007) have found a negative relationship between the number of employees, age of business and the number of innovation. Except for average $R \& D$ expenditure, there is a significant relation between other factors and the number of innovation.

Zhu and his colleagues (2011) compared the results of research the five key institution-based barriers to innovation in China: (1) competition fairness, (2) access to financing, (3) laws and regulations, (4) tax burden, and (5) support systems. These findings enhance the institution-based view of entrepreneurship by shedding light on how institution-based barriers affect innovation in SMEs.

According to Kenny and Reedys (2007) were asked whether their company's innovation strategy was proactive, reactive, pre-emptive or any combination of same. The most common strategy was proactive ( $n: 15)$, followed by reactive ( $n: 7)$. Two companies used both strategies while one company used all three strategies (proactive, reactive and pre-emptive).

Silva, Leitão and Raposo's (2007) study aims to identify the barriers to innovation that influence the innovation capability of Portuguese industrial firms. The results provide insights that high innovation costs have a negative and significant effect on the innovation propensity.

However, this survey is conducted on SMEs in Burdur, Turkey; findings might not be transferable to all SMEs in Turkey. Thus, it is recommended that further researches can be conducted on small-scale organizations and, also in different cities and countries for the generalizability of findings. This study provides an important theoretical insight into the innovation barriers encountered by SMEs, and presents empirical evidence to the innovation literature from Turkish SMEs in Burdur. As the findings of this research highlight some obstacles for Turkish SMEs, it also contributes to the developing country literature. In addition, in this study a particular sector is not focused due to the relatively limited number of small and medium sized enterprises in Burdur.

Innovation plays a significant role in today's business environment due to rapid globalization, advances in technologies and rapid change in consumers' demands. SMEs implementing the innovation activities find and benefit from new product and market opportunities. These SMEs develop in changing business environments and investigate the market for new opportunities. Moreover, These SMEs have many products or services and promote creativity and productivity. These SMEs prioritize new product development and innovation to meet new and changing customer needs and demands and to create new demands.

As a result of the findings, it was found that SMEs operating in Burdur implement the prospector and defender strategies. In prospector strategy, SMEs want to become an innovation leader in their sector. In defender strategy, SMEs want to try to reach the best performance in the field of a relatively narrow product-market. It is important to determine the innovation barriers. The results indicate the internal and external barriers. Internal barriers include the resistance of employees to innovation within SMEs. External barriers include the idea of taking the support from institution and organization is difficult 
Journal of Global Strategic Management | V. 6 | N. 2 | 2012-December | isma.info | 103-112 | DOI: 10.20460/JGSM.2012615777

because of the bureaucratic practices. In addition to these results, there are two types of innovation applied in SMEs. One is product innovation, the other is process innovation. In product innovation, SMEs have at least one product patent. In process innovation, SMEs keep the records of process time. 


\section{REFERENCES}

Antonioli, D., Mazzanti, M., Pini, P. and Tortia, E. (2004), Adoption of techno-organizational innovations, and industrial relations in manufacturing firms: An analysis for a local industrial system. Economia Politica, 21 (1).

Bagozzi, R. P., Yi, Y. (1988), On the evaluation of structural equation models. Journal of the Academy of Marketing Science, Spring-16, pp. 74-94.

Cansız, M. (2008), Türkiye'de Kobiler ve KOSGEB, DPT Uzmanlık Tezleri, Ankara, Yayın No. 2782: 5 .

Carlson, C. R. and Wilmot, W. W. (2006), Innovation: The five disciplines for creating what customers want. Crown Publishing Group, NY.

Cormican, K. and O'sullg̀van, D. (2004), Auditing best practice for effective product innovation management. Technovation.

Croteau, A. M., Bergeron, F. (2001), An information technology trilogy: Business strategy, technological deployment and organizational performance, Journal of Strategic Information Systems 10, PII: S0963-8687 (01) 00044-0, pp. 77-99.

Çalıpınar, H. and Baç, U. (2007), The factors effectıng the realızatıon of ınnovatıon in smes and a field survey, Ege Academic Review, 7 (2), pp. 445-458.

Demirbaş, D. (2005), How do Entrepreneurs Perceive Barriers to Innovation? Empirical Evidence from Turkish SMEs. Newcastle Business School, Northumbria University, Newcastle upon Tyne, NE1 $8 \mathrm{ST}, \mathrm{UK}$.

Dengiz, B. and Belgin, Ö. (2007), KOBI'lerin iş süreçlerinde inovasyon: Benzetimin rolü. $I V$. KOBI'ler ve Verimlilik Kongresi Kongre Kitabı, 7-8 Aralık 2007, (Ed.: Gençy1lmaz, G.) İstanbul: İstanbul Kültür Üniversitesi Yay.

Ecevit, S., Işık, Z. and Işık, Ö. (2011), İnovasyon ve stratejik yönetim sinerjisi: Stratejik inovasyon. CBÜ Sosyal Bilimler Dergisi, 9 (2), pp. 538-559.

Fatoki, O. O. (2011), The impact of human, social and financial capital on the performance of small and medium-sized enterprises (SMEs) in South Africa. Kamla-Raj 2011. J Soc Sci, ISSN 0971-8923, 29 (3): 193-204.

Günay, Ö. (2007), Kobi’lerde yenilik türlerinin analizi ve yenilik engellerinin belirlenmesine yönelik bir araştırma. İstanbul Üniversitesi, Sosyal Bilimler Enstitüsü, İşletme Anabilim Dall, İsletme Yönetimi ve Organizasyon Bilim Dal, Yüksek Lisans Tezi, s. 32-33.

Hadjimanolis, A. (1999), Barriers to innovation for SMEs in a small less developed country (Cyprus). Technovation 19, pp. 37.

Hambrick, D. C. (1983), Some tests of the effectiveness and functional attributes of Miles and Snow's strategic types. Academy of Management Journal, Vol. 26, No: 1, pp. 5-26.

Kenny B. and Reedy E. (2007), "The Impact of Organizational Culture Factors on Innovation Levels in SMEs: An Empirical Investigation”, The Irish Journal of Management, 5,(17), pp.119-142

Leskovar, S. G. and Bastic, M. (2007), Differences in organizations' innovation capability in transition economy: Internal aspect of the organizations' strategic orientation. Technovation 27, doi:10.1016/j.technovation.2007.05.012, pp. 533-546.

Miles, R. E. and Snow, C. C. (2003), Organizational strategy, structure, and process. Stanford University Press, Stanford, California, p. 29.

Mone, M. A., McKinley, W. and Barker III, V. L. (1998), Organizational decline and innovation: A contingency framework. Academy of Management Review, 23 (1), pp.115-132.

Nunally, J. C. (1978), Psychometric theory. McGraw-Hill, ISBN 0070474656, 2nd Ed., NY.

Oslo Guide. (2005), Yenilik verilerinin toplanması ve yorumlanması için ilkeler. OECD ve Eurostat ortak yayımı. 3. Bask1, 
http://www.tubitak.gov.tr/tubitak_content_files/BTYPD/kilavuzlar/Oslo_3_TR.pdf. (Retrieved: Jan. 11, 2012).

Örücü, E., Kılıç, R. and Savaş, A. (2011), Kobi’lerde İnovasyon Stratejileri ve İnovasyon Yapmayı Etkileyen Faktörler: Bir Uygulama, Doğuş Üniversitesi Dergisi, 12 (1), pp. 58-73.

Piatier, A. (1984), Barriers to Innovation. London. Frances Pinter, pp. 46.

Silva, M., Leitão, J. and Raposo, M. (2007). Barriers to innovation faced by manufacturing firms in Portugal: How to overcome it?. MunichpersonalRePEcArchive. Acedido a 20 de dezembro em: http://mpra.ub.uni-muenchen.de/5408/.

Smith, K. G., Guthrie, J. P., Chen, M. J. (1989), Strategy size and performance. Organizational Studies, 10 (1), pp. 63-81.

Tajeddini, K. (2010), Effect of customer orientation and entrepreneurial orientation on innovativeness: Evidence from the hotel industry in Switzerland. doi:10.1016/j.tourman.2009.02.013, Tourism Management 31, pp. 221-231.

TUIK. Türkiye İstatistik Kurumu. (2008), Yenilik araştırması 2004-2006. Haber Bülteni, Sayı : 23.

Zahra, S. A. and Pearce II, J. A. (1990), Research evidence on the Miles and Snow typology. Journal of Management, 16 (4), pp. 751-768.

Zhu, Y., Wittmann, X. and Peng, M. W. (2011), Institution-based barriers to innovation in SMEs in China, Asia Pac J Manag, DOI: 10.1007/s10490-011-9263-7, pp. 1-12. 